Łukasz Mazur

Uniwersytet Papieski Jana Pawła II w Krakowie

\title{
HANS JONAS I ALAN WATTS: TEODYCEA A MIT SPEKULATYWNY
}

W niniejszym artykule chciałbym skonfrontować ze sobą dwa oryginalne mity spekulatywne ściśle związane z tematyką teodycealną. Pierwszy z nich - autorstwa Hansa Jonasa - to mit inspirowany kabałą, którym Jonas posłużył się w znanym eseju Idea Boga po Auschwitz. Drugi mit to oparta na motywach hinduistycznych spekulacja na temat „śpiącego Boga”; autorem owej „opowiastki” z cyklu: „Wyobraź sobie, że...” jest brytyjski pisarz i mówca Alan Watts.

Inspirację dla opracowania zagadnienia w wyżej wymieniony sposób stanowi fakt, że religiom takim jak buddyzm czy hinduizm - w ramach których antropologia, eschatologia oraz stosunek do historii i związanego z nią cierpienia pojmowane są w zgoła inny sposób niż w kulturze duchowo zakorzenionej w glebie judeochrześcijańskich wartości - również zależy na usprawiedliwieniu Boga bądź „najwyższej rzeczywistości” w kwestii obecnego w ludzkich dziejach zła. Dystynkcję w podejściu do tego samego problemu dosadnie podkreśla odmienny punkt wyjścia w rozważaniach obu myślicieli. Podczas gdy Jonas zdaje się sądzić, że dla wierzących żydów zbrodnia tak wielka, jak ta, której dokonano w Auschwitz, stanowi zarówno wyzwanie dla rozumu, jak i sprawdzian wiary - jest więc sprawą życia i śmierci, nadziei i rozpaczy w kwestii wyznania - Watts, mówiąc o całym cierpieniu i niepokoju związanym z ludzką egzystencją w czasie i przestrzeni, pyta dosłownie: „Czy to poważne?” i odpowiada również wprost: „Nie!”. 
Na koniec należy postawić pytanie: dlaczego mit? Dlaczego obydwaj autorzy - przy wszystkich różnicach, które ich dzielą - postanowili, w tej szczególnej kwestii, posłużyć się mitem? Czy w konfrontacji ze złem, które ma miejsce na naszych oczach - w historii, którą dzielimy i w której współuczestniczymy - nie możemy zadowolić się żadnym zgrabnym wyjaśnieniem, logicznie spójną spekulacją, taką jak chociażby teodycea w wersji zaproponowanej przez Leibniza? Czy mit rzeczywiście może zadośćuczynić Bogu i nam samym? Jeśli tak, to dlaczego?

\section{1. „ŚPIĄCY BÓG” ALANA WATTSA}

Już sam początek wykładu, który prezentuje Watts w jednym z rozdziałów Beyond Theology, zapoznaje nas z czysto spekulatywną metodą argumentacji. Podejmuje się on bowiem próby stworzenia religijnej narracji w formie „czystej zabawy”, „fantazji”, „dzieła sztuki” - słowem: eksperymentalnej spekulacji, która rozwiałaby nasze wątpliwości, oferując zadowalające odpowiedzi na gnębiące nas pytania. Pisze Watts:

Dlaczegóż by zatem nie spytać o najbardziej estetycznie zadowalające wyjaśnienie czyjejś własnej egzystencji w naszym szczególnym wszechświecie? Musi to być wyjaśnienie, które całkowicie zadowoli mnie nawet w najbardziej przerażających męczarniach, których można doświadczyć w tym świecie. Pod jakimi warunkami byłbym faktycznie chętny je znosić? ${ }^{1}$

Pierwszą, chybioną zdaniem Wattsa, próbą odpowiedzi na tak postawione pytanie jest powołanie się na prawo karmy - prawo dziedziczenia zasług i win dotyczących tak naszego własnego życia, jak i poprzednich wcieleń. We wprowadzeniu do buddyjskiej historii i nauk czytamy:

1 A. Watts, Beyond Theology: The Art of Godmanship, New York 1973, s. 116; tłum. za: http://alanwatts.republika.pl/czy1.html (1.04.2018). 
Tak więc skutki naszych działań nie znikają w chwili śmierci. Sytuacje, pozytywne jak i te negatywne, których nie zamkniemy w tym życiu, podążą za nami do następnego. Jak w reakcji łańcuchowej, jedno życie przechodzi w następne jednocześnie je warunkując. To jest koło narodzin i śmierci, „stan tułaczki” - samsara (...) Co więcej karma oznacza, że nic nie dzieje się przypadkiem. Wszystko ma sens, a dokładniej przyczynę. To kim teraz jesteśmy, nasze umiejętności i ograniczenia, to, co się nam przydarza w ostatecznym rozrachunku są to wszystko dojrzałe owoce naszych przeszłych decyzji².

Watts wyraźnie dystansuje się od tego typu rozwiązań; powołać się na prawo karmy w tym konkretnym przypadku oznacza „wylać dziecko z kąpielą” - na pytanie o to, jak obronić „absolut”, odpowiadamy bowiem, skazując podmiot, który owe pytanie wysunął.

Popularny hinduizm i buddyzm - pisze Watts - wyjaśniają takie tragedie jako osobistą karmę, czyjeś własne działanie odziedziczone z poprzedniego życia. Dziecko z syfilisem płaci zatem cenę za jakieś zło, które uczyniło w poprzednim wcieleniu. Lecz jest to nie tyle wyjaśnienie, ile nieokreślone odroczenie wyjaśnienia. Dlaczego i jak odradzająca się jednostka pierwszy raz styka się z niepowodzeniem? Odpowiedzialność za czyjeś własne cierpienie nie może być przypisana jednostce, jaką znamy i widzimy powierzchownie, gdyż na tym poziomie jednostka dorosła lub niemowlę - wydaje się o wiele bardziej ofiarą niż sprawcą swej własnej męczarni ${ }^{3}$.

Już na tym poziomie możemy wytropić paralelę pomiędzy refleksją hinduizmu czy buddyzmu a myślą judeochrześcijańską. Czy uczniowie nie pytają Jezusa: „Rabbi, kto zgrzeszył, że się urodził niewidomy - on czy jego rodzice?" (J 9, 2); czy sam Bóg nie formułuje następującej przestrogi (Wj 20, 5-6):

2 B. Scherer, Buddyzm, tłum. G. Kuśnierz, Kęty 2009, s. 41.

${ }^{3}$ A. Watts, Beyond Theology..., s. 118. 
Ja Pan, twój Bóg, jestem Bogiem zazdrosnym, który każe występek ojców na synach do trzeciego i czwartego pokolenia względem tych, którzy Mnie nienawidzą. Okazuję zaś łaskę aż do tysięcznego pokolenia tym, którzy mnie miłują i przestrzegają moich przykazań.

Wyobrażenie o związku grzechu i winy z ludzkim cierpieniem znane było bowiem nie tylko na Dalekim Wschodzie. Świadectwo tych wyobrażeń odnaleźć możemy również w sentencjach rabinistycznych oraz w znacznie późniejszych tekstach Talmudu: „Nie ma śmierci bez

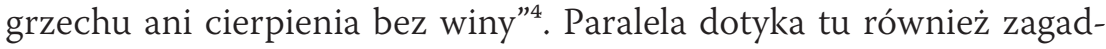
nienia wolnej woli.

Z perspektywy monistycznej metafizyki „filozofii Indii” problematyczność zagadnienia karmy może nasuwać się samorzutnie - ciąg „niewygodnych” wcieleń skutków musi gdzieś posiadać swoje źródło - przyczynę. Jeśli bowiem:

(...) wewnętrzna najgłębsza istota we wszystkich rzeczach jest ewidentnie jedna i ta sama, a jej tajemnicę nosi człowiek w sobie - klucz do zagadki istotowości świata (Brahmana) jest więc kluczem antropologicznym, skrojonym na miarę naszego poznającego i chcącego "ja” $(\text { atmana })^{5}$.

- to uzasadnione zdaje się pytanie: skąd w skutku cierpienie i zło, których nie zna doskonała, boska przyczyna?

Odpowiedzią na to pytanie ma być sam proces indywiduacji. Principium individuationis to egoizm stanowiący o ujednostkowieniu woli, uwikłaniu w czas i przestrzeń, określający stosunki między pojedynczymi rzeczami a naszą własną osobą. Jak wyjaśnia Schopenhauer: „Ten jednak, kto przeniknąwszy principium individuationis poznaje istotę rzeczy samych w sobie i tym samym całokształt (...) widzi siebie równocześnie

4 Shabbat 55a.

${ }^{5}$ J. Marzęcki, Artur Schopenhauer wobec filozofii Indii, Warszawa 1992, s. 5. 
we wszystkich miejscach i opuszcza krąg" ${ }^{6}$. Skąd jednak sam mechanizm indywiduacji? Wydaje się bowiem, że działa on gdzieś pomiędzy idealną podstawą bytu - Brahmanem - a jej empirycznym, ograniczonym przejawem: atmanem (czyli Ja). Próba obwinienia Ja za rodowód i sposób funkcjonowania owego mechanizmu wydaje się zaś bezzasadna. Wszyscy wszak, dzieląc tę samą istotę, dziedziczymy w zasadzie jedną i tę samą winę w karmicznym kołowrocie wcieleń - trudno jednak w tej sytuacji wskazać jednoznacznie na jej pochodzenie.

W swojej spekulacji Watts częściowo operuje tradycyjnym hinduistycznym rozumieniem omawianej kwestii, słusznie wyrażając jednak przy tym swoje zastrzeżenia. Ani „wyjaśnienie” karmiczne, wedle którego zło i cierpienie stanowią element swoistego „porządku świata”, ani buddyjski postulat nierealności owego świata, a wraz z nim również zła i cierpienia, nie mogą - zdaniem Wattsa - zadowolić niewinnej (choć obwinianej za niedogodność swojej egzystencji), skazanej na ból jednostki. Jak mówi Watts:

\begin{abstract}
Musimy zatem wyobrazić sobie nowy rodzaj indywidualności, w którym są dwie strefy o wspólnym środku. Zewnętrzna sfera jest ograniczoną świadomością, ego, powierzchowną jednostką, która uważa się za podmiot czynów i doświadczeń, bądź biernie cierpiącą. Lecz wewnętrzna strefa jest prawdziwym „ja”, nieznanym świadomemu ego. Albowiem to ostatnie jest czasowym przebraniem albo snem tego pierwszego, a prawdziwa Jaźń nie tylko nie bałaby się wkraczać w sny o żywym cierpieniu, lecz przez cały czas doświadczałaby procesu jako radości i błogości, jak w wiecznej grze w chowanego ${ }^{7}$.
\end{abstract}

Tutaj dopiero zaczyna się zasadnicza część mitologiczno-teodycealnej spekulacji, którą proponuje nam Watts:

${ }^{6}$ A. Schopenhauer, Świat jako wola i przedstawienie, tłum. J. Garewicz, Warszawa 1994, S. 573.

7 A. Watts, Beyond Theology..., s. 118. 
Ta fantazyjna religia wymagałaby wtedy ostatecznego warunku, że któregoś razu te dwie sfery stopiłyby się, że moje najskrytsze „Ja” obudziłoby się ze swego snu, by przemienić moje powierzchowne ego szokiem poznania. Może to dlatego mamy czasem dziwnie przyjemne wrażenie zapomnienia czegoś ogromnie ważnego dawno, dawno temu. Okazjonalnie ten cień pamięci przybywa jako aluzja zapomnianego raju, jakiś jasny krajobraz wzgórz i wód, który jest całkowicie znany, a jednak zupełnie niezidentyfikowany. Od czasu do czasu „prawdziwy” świat przypomina nam o tym i myślimy: „Tego zawsze szukałem. To miejsce jest jak dom”. Innymi razy wspomnienie ma o wiele głębszy wymiar - wrażenie bycia niezmiernie starym i wiedzącym, jakoś poza czasem i przestrzenią. Lecz nie ma w tym nic konkretnego, bo choć wrażenie jest żywe, to jest ono boleśnie efemeryczne. Są to zatem napomknienia czegoś do zapamiętania, czegoś, co jest ogromnym wymiarem mojego istnienia, który pozostawał ukryty być może od momentu narodzin. Gdyż świadomość, świadoma uwaga, jest sztuczką zauważania figury i ignorowania tła, a w ten sam sposób wydaję się zauważać moje ego i zapominać o moim tle, większej Jaźni, która leży u podstaw mojego ego ${ }^{8}$.

Watts odsłania tu dwa kluczowe dla swojego spekulatywnego mitu pojęcia: sen i przebudzenie. Kto śpi? Bóg, a śpiąc - staje się człowiekiem, jego światem, historią itd. Oddaje się immanencji, stając się jej zasadniczą substancją. Sen jest więc sprawą zarówno Boga, jak i człowieka; sprawą transcendencji i immanencji - ów sen to ich wspólny „interes”. Sen przeplata się z jawą, nie można więc powiedzieć, że śniący przestaje istnieć, chodź znajduje się w stanie łudzącego zawieszenia pomiędzy kolejnymi odsłonami życia w pełni świadomego.

Bliskie pokrewieństwo życia i snu występuje tu bardzo wyraźnie (...) Wedy i Purany nie znają dla całego poznania rzeczywistego świata, które

8 A. Watts, Beyond Theology..., s. 119. 
nazywają zasłoną mai lepszego porównania i żadnego nie stosują częściej niż snu?

Sen nie przerywa egzystencji, raczej zmienia w danej chwili „styl” egzystowania, jest więc doskonałą metaforą samsary jako kręgu życia, w obrębie którego Bóg raz za razem podejmuje wyzwanie wcielenia. Jak w wierszu Leśmiana: „A my stójmy zwartym kołem / I śnijmy się Bogu społem / Póki czas jeszcze"10.

Watts powoli zbliża się w swojej spekulacji do wyłożenia odpowiedzi na postawione pytanie: pod jakimi warunkami byłbym naprawdę chętny znosić nawet najbardziej przerażające męczarnie? Elementem kluczowym okazuje się właśnie metafora snu:

To jest mniej więcej to, co bym zrobił, gdybym miał moc śnienia każdej nocy o czymkolwiek bym chciał. Przez parę miesięcy spełniłbym prawdopodobnie wszystkie co oczywistsze życzenia. Byłyby pałace i bankiety, muzyka i tańczące dziewczyny, bajeczne spotkania miłosne i ogrody przy jeziorach z górami w tle. Następnie długie rozmowy z mędrcami, kontemplacja dzieł sztuki, słuchanie i granie muzyki, podróże do obcych krajów, loty w przestrzeń, by zobaczyć galaktyki, oraz nurkowanie w głąb atomu, by oglądać drgające falo-cząsteczki. Lecz przyszłaby noc, że zachciałbym dodać nieco smaku przygody - być może sen o niebezpiecznej wspinaczce górskiej, o ratowaniu księżniczki przed smokiem czy nawet lepiej - nieprzewidywalny sen, w którym nie wiem, co się wydarzy. Zaraz po tym mogę stawać się coraz śmielszy. Mógłbym chcieć śnić całe żywoty, mieszcząc siedemdziesiąt lat w jednej nocy. Śniłbym, że wcale nie śnię, że się nigdy nie obudzę, że całkowicie zagubiłem się gdzieś w pogmatwanych korytarzach umysłu i w końcu - że znoszę tak

\footnotetext{
${ }^{9}$ J. Marzęcki, Artur Schopenhauer..., s. 51.

${ }^{10}$ B. Leśmian, W przeddzień swego zmartwychwstania, w: B. Leśmian, Łąka, Kraków 2009, S. 102.
} 
nieznośne męczarnie, że gdy obudzę się, to będzie to lepsze od wszystkich możliwych snów ${ }^{11}$.

W związku z powyższym należy odnotować, że Watts niemalże niepostrzeżenie przenosi „ciężar” winy z wyłącznie śnionej czy też będącej częścią treści snu jednostki na boski podmiot śniący swój nieprzewidywalny „sen o świecie”.

Jednocześnie zmienia się wartość owego „ciężaru”: z winy w rodzaj gry, zabawę, sprawdzian możliwości, przygodę. Takie przewartościowanie sprawia, że „ciężar” w zasadzie znika - staje się lekkością gry; przymus i skrępowanie, bycie zależnym od zła i cierpienia stają się najwyższą swobodą, wolnością, która nie cofa się nawet przed zanegowaniem swojej sprawczej wszechmocy.

Na zakończenie Watts pisze:

Do teraz jasne powinno się stać, że moja ukryta Jaźń mogłaby równie dobrze wyobrażać sobie tę konkretną sytuację i osobowość, w której się teraz znajduję. To samo byłoby prawdą dla każdej innej osoby, gdyż według naszej hipotezy najskrytsza Jaźń jest w centrum wszystkich ludzi. Cała inność, cały dualizm, cała różnorodność jest częścią sztuki. Stąd lekcją z tej fantazji jest to, że przez wytrwałe przemyśliwanie moich najmilszych marzeń, dla wyjaśnienia tego wszechświata i poprzez próbę wyobrażenia sobie jak najlepiej natury wiecznej błogości mogę chcieć wrócić do miejsca, gdzie znajduję się teraz. Jest proste zabezpieczenie, że cały żal za przeszłe i obecne cierpienie może być usunięty i przemieniony w radość poprzez obudzenie się i odkrycie, że ja jako najskrytsza Jaźń naumyślnie o tym śniłem i że było to integralną częścią rozkoszy, którą Jaźń cieszy się przez całą wieczność ${ }^{12}$.

Tę samą sytuację, w nieco odmienny sposób, komentuje Michał Fostowicz:
11 A. Watts, Beyond Theology..., s. 121.
12 A. Watts, Beyond Theology..., s. 121-122. 
Szczęśliwy, śpiący Wisznu spoczywa na zwojach wielkiego węża Anaty, unosząc się w kosmicznym Oceanie Mlecznym. Przed nim, jak na wysuniętej do przodu scenie, widnieje sześć postaci, które symbolizują umysł i pięć zmysłów. One są obudzone i w pełni działania, podczas gdy Bóg pogrążony jest we śnie. Są to więc istoty (...) pełne świadomości i poczucia własnej autonomii, reprezentują świat zjawisk. Skądinąd wiemy, że świat w perspektywie tych istot pozbawiony jest boskiej harmonii i spokoju. Wyłania się z głębi, gdzie wszystko jest jednością i błogością, a przejawia się jako wielość, ograniczoność i związane z tym konflikty i cierpienia. Rzec można, że Bóg śni jakiś koszmar ${ }^{13}$.

Pytanie, czy z perspektywy bohatera owej koszmarnej scenerii rzeczywiście skłonny byłbym bez zastrzeżeń przyjąć wyjaśnienie Wattsa; czy nie wymaga ono nierealnego wręcz wysiłku przerzucenia akcentu z samego siebie na boski podmiot; czy wziąwszy się w nawias do tego stopnia, będę w ogóle potrzebował jeszcze jakichkolwiek teodycealnych teorii? Swego rodzaju niekonsekwencję stanowi również fakt, że hinduiści, mocniej nawet niż buddyści, podkreślają niedogodność wcielenia i kolejnych narodzin; przez całe życie dążą bowiem do oczyszczenia karmy, swego rodzaju odpokutowania, które na celu ma opuszczenie zaklętego kręgu samsary.

Jednakowoż to tylko mit: metafora czy - jak mówi Watts - fantazja. Mogę czuć się dzięki niemu pocieszony, pokrzepiony perspektywą przebudzenia, mogę jednak równie dobrze podać go w wątpliwość. Mit Wattsa ma w sobie bowiem coś z gnozy: muszę stać się „wiedzącym”, by zaakceptować aktualny stan rzeczy oraz wszystkie związane z nim konsekwencje. Gdy już „wiem”, gdy poczyniłem już konieczny wysiłek, mogę cieszyć się z bycia „krokiem” w rozkosznym tańcu bóstwa, nawet jeśli z mojej perspektywy wydaje się on tańcem śmierci i zniszczenia; czy też dlatego, że jest on właśnie takim tańcem.

Ostatecznie nie należy, zdaniem Wattsa, choć mamy to w zwyczaju, być śmiertelnie poważnym wobec roztrząsanych tu kwesti. Świat to tylko

${ }^{13}$ M. Fostowicz, Boska analogia, Gdańsk 20o8, s. 97. 
gra, taniec i rozkosz. Za ich fasadą nie czeka nas - mówi Watts - ani gniew, ani żaden krwawy sąd czy wyrok skazujący naszą duszę na wieczne potępienie, jedynie jeszcze więcej rozkoszy; być może również ukojenie i zadowolenie, jeśli wcześniej przejrzeliśmy na wskroś boskie zamiary.

Na dowód Watts wieńczy swoją spekulację osobliwymi słowami Dantego:

„Ojcu, Synowi i Duchowi Świętemu - zaczął śpiewać cały Raj - niech będzie chwała!" - upojony tak byłem jego słodkością. A co zobaczyłem przed moimi oczami, wydawało się śmiechem wszechświata, za pomocą którego moje upojenie znalazło wejście tak przez dźwięk, jak i widok.

I dodaje: „Jeśli zatem, tak jak sugeruje Dante, anielski hymn oddający cześć Świętej Trójcy brzmi jak śmiech wszechświata, to co jest Żartem?"14.

\section{HANS JONAS I „BÓG CIERPIĄCY”}

Można zaryzykować stwierdzenie, że próba, którą podejmuje Hans Jonas wobec ofiar Auschwitz - najstraszliwszej ze zbrodni, które nawiedziły współczesny świat - stanowi jedynie desperacką „odpowiedź na ich dawno ucichły krzyk do milczącego Boga" ${ }^{15}$. W przeciwieństwie do Wattsa Jonasowi daleko do niezaangażowanego obiektywizmu, jaki powinien charakteryzować filozofa, nie wspominając nawet o „śmiechu", którym ten pierwszy kwituje ludzkie dzieje. Dzielą oni natomiast zasadnicze teodycealne pytanie: jaki Bóg mógł pozwolić, by coś takiego się wydarzyło?

Na wstępie Jonas przybliża nam zagadnienie przez porównanie sytuacji wierzących żydów z położeniem chrześcijan, którzy również doświadczeni zostali przez „piekielną” obozową rzeczywistość:

\footnotetext{
${ }^{14}$ A. Watts, Beyond Theology..., s. 124.

${ }^{15}$ H. Jonas, Idea Boga po Auschwitz, tłum. G. Sowiński, Kraków 2003, s. 31.
} 
Należy zauważyć, że z teologicznego punktu widzenia żyd jest wobec tego pytania w trudniejszej sytuacji niż chrześcijanin. Albowiem dla chrześcijanina, który prawdziwego zbawienia oczekuje od transcendencji, ziemski świat i tak w ogromnej mierze należy do diabła i jest przedmiotem nieufności - zwłaszcza, w następstwie grzechu pierworodnego, świat człowieka. Natomiast dla żyda, który ziemski świat postrzega jako miejsce Bożego stworzenia, Bożej sprawiedliwości, Bożego odkupienia, Bóg eminentnie jest Panem historii - i tu „Auschwitz” nawet w oczach wierzących żydów kwestionuje tradycyjne pojęcie Boga ${ }^{16}$.

Z tego właśnie względu należy według Jonasa prześwietlić „tradycyjne pojęcie Boga”, jeśli nie chcemy zwyczajnie od tego pojęcia - a wraz z nim być może również od wiary - odstąpić. Wszak za pomocą „dawnych kategorii teologicznych” nie sposób uporać się z żydowskim doświadczeniem historii, jakie pozostawiło po sobie wydarzenie „Auschwitz”.

Tutaj z pomocą przychodzi Jonasowi kabalistyczny mit - czy też jego spekulatywne przekształcenie, które następnie posłuży filozofowi do rewizji relacji zachodzących pomiędzy klasycznie pojętymi przymiotami Boga:

Na początku mocą niedocieczonego wyboru, boska podstawa bytu podjęła decyzję, że powierzy siebie przypadkowi, ryzyku i niezmierzonej wielorakości form stawania się. Uczyniła to totalnie, weszła w przygodę czasu i przestrzeni, niczego z siebie nie zatrzymując; żadna jej część nie pozostała nieogarnięta i nietknięta, by z tamtego świata nadzorować, korygować i ubezpieczać okrężne kształtowanie jej losu w świecie stworzenia. Za tą bezwarunkową immanencją opowiada się nowoczesny duch. Jest świadectwem jego odwagi czy jego rozpaczy, a na pewno jego gorzkiej uczciwości, że poważnie traktuje nasz byt w świecie: że postrzega świat jako pozostawiony samemu sobie, jego prawa jako nie dopuszczające żadnej ingerencji, a naszą ścisłą przynależność do ziemskiego świata jako niezłagodzoną przez pozaświatową opatrzność. To samo postuluje

${ }^{16}$ H. Jonas, Idea Boga..., s. 33. 
nasz mit o bycie Boga w świecie. Wszelako nie w sensie panteistycznej immanencji: gdyby Bóg i świat były po prostu tożsame, świat w każdej chwili i w każdym stanie ukazywałby Jego pełnię, a Bóg nie mógłby ani zyskać, ani stracić. Przeciwnie, aby świat zaistniał, Bóg zrzekł się swego własnego bytu; pozbawił się swego Bóstwa, aby je na powrót otrzymać od odysei czasu, obładowane przypadkowym plonem nieprzewidywalnego doświadczenia czasowego, przemienione czy może też zniekształcone przez nie. W takim samoporzuceniu własnej nienaruszalności, gwoli nieograniczonego stawania się, nie może być mowy o innej antycypującej wiedzy niż antycypująca wiedza o możliwościach, których dzięki swym własnym warunkom użycza byt kosmiczny: właśnie tym warunkom Bóg wydał swą sprawę, gdy się wyzbył siebie dla świata ${ }^{17}$.

Pobrzmiewa tu echo Wattsowego „śpiącego Boga”, pozbawione jednak pozytywnych akcentów: jest „ryzyko”, „przypadek” i „niezmierzona wielorakość form stawania się", jednak raczej z naciskiem na niepokój związany z wyrzeczeniem, niezłomność w poświęceniu i ofiarności wielką niewiadomą.

Mit wszak opiera się na wątkach kabalistycznych; głównie na Luriańskiej idei cimcum: „skurczenia się”, „cofnięcia”, „ograniczenia samego siebie”. Jak wyjaśnia Czesław Miłosz w Ziemi Ulro:

Skoro wierzymy w Boga, stworzenie świata ex nihilo wydaje się niemożliwe, jako że Bóg, nieskończony, obejmuje wszystko i jakakolwiek przestrzeń poza nim równałaby się ograniczeniu jego nieskończoności. Dlatego Luria wprowadza pojęcie cimcum, czyli dobrowolnego wycofania się Boga, co bywa porównywane do wciągnięcia oddechu. W ten sposób Bóg stwarza przestrzeń primordialną, pierwsze „zewnątrz"18.

Początek odysei czasu stanowi właśnie ów akt „przedustawnej ofiary”, na który Bóg decyduje się w swej bezgranicznej dobroci.

\footnotetext{
${ }^{17}$ H. Jonas, Idea Boga..., s. 34-35.

${ }^{18}$ C. Miłosz, Ziemia Ulro, Kraków 1994, s. 147.
} 
Wróćmy jednak do spekulacji Jonasa:

Przez wieki Jego sprawa była bezpieczna w powoli pracujących rękach kosmicznego przypadku i prawdopodobieństwa - gdy, jak możemy przypuszczać, cierpliwa pamięć o krążeniu materii gromadziła się i wzrastała w intuicyjne oczekiwanie, którym wieczność w coraz większym stopniu towarzyszyła dziełom czasu - powolne wynurzanie się transcendencji $\mathrm{z}$ nieprzejrzystej immanencji ${ }^{19}$.

Wraz ze złożonością wzrasta ryzyko, potęguje się jednak również różnorodność możliwości zapośredniczenia Boga w świecie. Transcendencja - już nie wyłącznie sama dla siebie - zaczyna jakoby "przezierać” przez powierzchnię świata. Następujący nieco dłuższy fragment doskonale oddaje proces owej autoafirmacji:

A potem pierwsze poruszenie życia - nowy język świata; wraz z życiem zaś niebywałe spotęgowanie zainteresowania w wiekuistej sferze i nagły skok we wrastaniu ku ponownemu osiągnięciu pełni. Stające się Bóstwo czekało na kosmiczny przypadek, za którego sprawą ukazały się pierwsze oznaki, że Jego hojna stawka w końcu się zwróci. Dzięki nieskończenie wzbierającemu falowaniu odczuwania, postrzegania, dążenia i działania, falowaniu, które w coraz bardziej wielorakich i intensywnych formach wznosiło się ponad niemymi wirami materii, wieczność uzyskała siłę, napełniła się treściami autoafirmacji - i budzący się Bóg po raz pierwszy mógł powiedzieć, że stworzenie było dobre. Ale proszę zwrócić uwagę, że wraz z życiem pojawiła się śmierć i że śmiertelność jest ceną, jaką musiała za siebie zapłacić nowa możliwość bytu. Gdyby celem było ciągłe trwanie, życie nie miałoby się prawa rozpocząć, albowiem w żadnej ze swych możliwych form nie może się ono mierzyć z trwałością ciał nieorganicznych. Jest odwoływalnym i zniszczalnym bytem, przygodą śmiertelności, przygodą, która od długowiecznej materii na jej warunkach - na warunkach krótkotrwałego istnienia organizmu, w którym

${ }^{19}$ H. Jonas, Idea Boga..., s. 35. 
zachodzi przemiana materii - tytułem pożyczki otrzymuje skończoną przestrzeń dla indywidualnych istnień. Lecz właśnie w tym na krótko utwierdzonym samoodczuwaniu, działaniu i cierpieniu skończonego indywiduum - które dopiero ciśnieniu skończoności zawdzięczają całą intensywność, a tym samym świeżość doznawania - boski pejzaż rozwija swą grę barw, a Bóstwo zaczyna doświadczać samego siebie... ${ }^{20}$

Również tutaj, jak u Wattsa, większa nieprzewidywalność odpowiada wyższemu stopniowi afirmacji - póki co można tu jeszcze mówić o przyjemności, którą transcendencja czerpie z przebierania w niemalże nieskończonych zasobach form życia.

Proszę też zwrócić uwagę, że w niewinności życia przed pojawieniem się wiedzy sprawa Boga nie może pobłądzić. Wszelka różnica gatunkowa, jaką wyłania proces ewolucji, do możliwości odczuwania i czynu dodaje własne możliwości, wzbogacając samo doświadczenie boskiej podstawy. Każdy wymiar odpowiedzi świata, jaki otwiera się w toku ewolucji, dla Boga oznacza nową sposobność wypróbowania swej ukrytej istoty, odkrywania samego siebie dzięki niespodziankom przygody świata. Cały plon udręczonego trudu ewolucji, jasny czy ciemny, powiększa transcendentny skarb temporalnie przeżywanej wieczności. Odnosi się to już do rosnącego spektrum wielorakości form, a jeszcze bardziej do potężniejącej czujności i namiętności życia, która idzie w parze z bliźniaczym wzrostem postrzegania i ruchu w królestwie zwierząt. Coraz większe wyostrzanie się popędu i lęku, przyjemności i bólu, triumfu i niedostatku, miłości i nawet okrucieństwa - przenikliwość ich intensywności, w ogóle wszelkiego doświadczenia, jest zyskiem boskiego podmiotu, a ich niezliczoną ilość razy się powtarzające, lecz nigdy nietępiejące przeżywanie (już stąd konieczność śmierci i nowych narodzin) dostarcza oczyszczonej esencji, z której Bóstwo od nowa siebie buduje. Ewolucja przyczynia się do tego wszystkiego swą zbytkowną grą i surową dyscypliną. Jej twory, gdy się spełniają zgodnie ze

${ }^{20}$ H. Jonas, Idea Boga..., s. 35. 
swym popędem, usprawiedliwiają Boże ryzyko. Nawet ich cierpienie pogłębia pełnię dźwięków symfonii. Dlatego Bóg, w horyzoncie dobra i zła, nie może stracić w hazardowej grze ewolucji. Lecz ochraniając jej niewinność, nie może też prawdziwie zyskać - i nowe oczekiwanie narasta w Nim jako odpowiedź na kierunek, jaki stopniowo przyjmuje nieświadomy ruch immanencji ${ }^{21}$.

A więc „lęk”, „ból”, „niedostatek”, nawet „okrucieństwo” - wszystko to dopełnia i ubogaca pozytywną stronę możliwości związanych z przejawianiem się Boga w świecie. Bez nich - zdaje się sugerować Jonas - Bóg nie doświadczałby Siebie w pełni.

W tym punkcie zasadnicza myśl narracji niemieckiego filozofa wydaje się skrajnie podobna do myśli zawartej w omawianej wyżej „opowiastce” Wattsa. Prawdziwy „zysk” wydaje się jednak spoczywać poza granicami niewinności - stworzenie na „obraz i podobieństwo” realizuje się bowiem dopiero w wolności będącej odbiciem cimcum - dobrowolnego "cofnięcia” się Boga, aktu fundującego całość opisywanej przez Jonasa sytuacji.

A potem Bóg drży, ponieważ impet ewolucji, podtrzymywany przez Jego siłę napędową, przekracza próg, za którym kończy się niewinność, i zupełnie nowe kryterium sukcesu i fiaska przejmuje w posiadanie boską stawkę. Wraz z człowiekiem pojawia się wiedza i wolność; dzięki temu obosiecznemu darowi niewinność podmiotu życia, które samo siebie spełnia, czyni miejsce zadaniu odpowiedzialności w horyzoncie dysjunkcji dobra i zła. Odtąd szansom i niebezpieczeństwom tego wymiaru aktowego powierzona zostaje sprawa Boża, która teraz dopiero staje się jawna i której wynik waży się na szali. Wizerunek Boga, zapoczątkowany przez świat fizyczny, długo opracowywany - i nierozstrzygnięty - w zwężającej się spirali przedludzkiego życia, z tym ostatnim zwrotem i z dramatycznym przyspieszeniem ruchu przechodzi pod problematyczną pieczę człowieka, który może go spełnić, ocalić

${ }^{21}$ H. Jonas, Idea Boga..., s. 36. 
bądź zepsuć swym czynem. Właśnie na tym zatrważającym zderzaniu się jego czynów z Bożym losem, ich oddziaływaniu na stan wiecznego bytu polega ludzka nieśmiertelność ${ }^{22}$.

W odróżnieniu od absolutu postulowanego przez Wattsa - Bóg Jonasa nie przebudzi się ze swojego snu, nie otrząśnie się z rojenia, by odetchnąć z ulgą, gdyż to właśnie immanencji powierzone zostają tutaj losy świata. Parafrazując słowa Miłosza: innej nieśmiertelności nie będzie.

Wraz z powstaniem człowieka transcendencja przebudziła się ku samej sobie i ze wstrzymywanym oddechem odtąd towarzyszy jego czynowi, pełna nadziei i starań, z radością i ze smutkiem, z zadowoleniem i z rozczarowaniem - a także, jak chciałbym wierzyć, dając mu odczuć swą obecność, choć nie ingerując w dynamikę ziemskiego widowiska: albowiem czy nie mogłoby być tak, że transcendencja, odbijając jego stan, migoczący chwiejnym bilansem ludzkiego czynu, rzuca światło i cień na ludzki pejzaż ${ }^{23}$.

Tymi słowami Jonas kończy swoją spekulację.

Porównując oba mity, ciężko powstrzymać narzucające się skojarzenia, jednakże w punkcie dojścia otrzymujemy skrajnie różne wnioski. U Wattsa Bóg jest bytem, który rozkoszuje się grą świata - mimo że cierpienie i zło, które spotykamy na swojej drodze, są nieodłącznym składnikiem tej rozkoszy. U Jonasa natomiast Bóg całkowicie oddany sprawie immanencji przeżywa wraz z nią wszelkie możliwe stany; jest więc bytem wrażliwym, temporalnym, zmiennym, zatroskanym o swój lud i losy świata oraz - co najistotniejsze - cierpiącym niedostatek. Bóg cierpi wraz ze Swoim stworzeniem, a jednocześnie nie usuwa cierpienia, nie ingeruje w przebieg ziemskich wydarzeń; właściwie bez reszty

\footnotetext{
${ }^{22}$ H. Jonas, Idea Boga..., s. 36-37.

${ }^{23}$ H. Jonas, Idea Boga..., s. 37.
} 
powierzając swój los immanencji, nie może już ingerować w żadne ze zdarzeń, które rozgrywają się na jej scenie.

„Tym sposobem” - pisze Jonas - „dochodzimy do najbardziej krytycznego punktu naszego spekulatywnego eksperymentu teologicznego: Bóg nie jest wszechmocnym Bogiem!"24. Fakt istnienia zła nie daje się bowiem pogodzić z pojęciem wszechmocnego i bezgranicznie dobrego Boga - przynajmniej nie w perspektywie zdarzeń takich jak „Auschwitz”, gdy ludzkie cierpienie i towarzysząca mu skarga przerastają wszelką możliwą miarę, a Bóg mimo to uparcie „milczy”. Spekulacja Jonasa prowadzi do wniosku, że „milczenie Boga” jest wyrazem jego niemocy. W obliczu zła tylko dobry Bóg pozbawiony mocy jest Bogiem, którego można zrozumieć. Zrozumiałość i dobro - dwa z trzech klasycznie pojętych przymiotów bytu absolutnego - dają się ocalić za cenę boskiej wszechmocy.

WNIOSKI

Kiedy porównujemy mit Jonasa z tym zaprezentowanym przez Wattsa uderza fakt skrajnie odmiennej eschatologii. O ile u Wattsa Bóg otrząśnie się z immanencji niczym ze złego snu - być może tylko po to, by za moment znów zapaść w drzemkę - o tyle u Jonasa „scena świata” staje się permanentna do granic możliwości. W każdym z przypadków moneta może ukazać nam tylko jedno ze swoich oblicz: awers wymazuje rewers - i na odwrót. Dla teodycei kwestia odmiennej eschatologii bynajmniej nie jest sprawą obojętną, otwiera bowiem horyzont nadziei bądź zamyka w beznadziejności.

Wydaje się, że można słusznie powątpiewać w przedłożoną przez Jonasa absolutną immanentyzację „boskiej sprawy” - świadczy o tym chociażby silny głos Boga przemawiającego ze stronic Starego Testamentu; być może również mowa, którą Ezechiel kieruje do „wysuszonych kości” (Ez 37), czy też midrasze traktujące o połączeniu duszy i ciała.

${ }^{24}$ H. Jonas, Idea Boga..., s. 40. 
Z drugiej strony eschatologia w wersji zaproponowanej przez Wattsa kusi możliwością bycia zwolnionym z odpowiedzialności za dokonywane czyny; w końcu Bóg śni całą tę „opowieść” ku własnej uciesze, ważny jest zatem sam fakt bycia jej elementem, nieistotne - jakim.

Czemu jednak mówimy tu o eschatologii? Wydaje się, że logos mitów jest logosem tego, co "ostateczne” (eschaton) - ich logika wykracza bowiem poza dosłowność, by w przybliżeniu ukazać „rzeczy” przerastające nasze władze poznawcze; właśnie owa nieostrość i niedosłowność pozwalają wyjść poza standardowe sposoby myślenia. Pisze Jonas:

Nawiążę tutaj do wcześniejszej próby, na którą się kiedyś odważyłem w konfrontacji ze znacznie szerszym problemem nieśmiertelności (...) Posiłkowałem się wówczas wymyślonym przez siebie mitem - owym instrumentem obrazowych, ale wiarygodnych przypuszczeń, który Platon dopuszcza tam, gdzie myśl wychodzi poza granicę wiedzy ${ }^{25}$.

Właśnie tam, gdzie „myśl wychodzi poza granicę wiedzy”, mit okazuje się doskonałym, o ile nie jedynym, narzędziem poznawczym. Mit pozwala nam wykraczać poza to, co ściśle rozumne i logiczne, sięgać tam, gdzie nie sięga sztywna dyskursywna racjonalność.

Pozostaje pytanie: co lepiej opisuje naszą rzeczywistość? Czy nie jest tak, że przyzwyczajeni do jasności i jednoznaczności jako dyskomfort odczuwamy wszystko to, co wykracza poza te kategorie? Różnorodne teodycee wydają się jedynie świadectwem prób uporania się z owym dyskomfortem. Trafnie tę sprawę ujął Michał Fostowicz w eseju Świat bez prawdy:

Niemożność zracjonalizowania symboli zła nie jest jedynie manifestacją ich demonicznej irracjonalności w przeciwieństwie do racjonalnej natury dobra. Przeciwnie, oznacza ona niemożność sterowania dobrem i wymykanie się samego fundamentu rzeczywistości, którego nie sposób sprowadzić do jakichś oczywistych pojęć moralnych czy jasności

${ }^{25}$ H. Jonas, Idea Boga..., s. 34. 
prawdy. Oznacza więc skazanie na świat pogrążony w cierpieniu, niepewności i poczuciu winy. Zło pojmowane jako niemożność sterowania dobrem jest frustracją, ale jest ona wynikiem (uprzedniej) moralnej uzurpacji ${ }^{26}$.

W tej perspektywie Watts posuwa się dalej niż Jonas, który mitologiczną spekulację zaciąga w służbę pracy na pojęciach.

Jednakże w wypowiedzi wieńczącej esej Idea Boga po Auschwitz filozof jakby celowo posługuje się stwierdzeniem wieloznacznym, dając tym samym do zrozumienia, że wszystkie znane nam teodycee stanowią jedynie ułomną ludzką probę odpowiedzi na dręczący nas paradoks:

\begin{abstract}
Panie i Panowie! Wszystko to jest nieudolną wypowiedzią. Nawet słowa wielkich wizjonerów, proroków i psalmistów, z którymi nikt nie może się równać, były nieudolne w obliczu wiekuistej tajemnicy. Wszelka odpowiedź na pytanie Hioba również nie może być niczym więcej. Moja odpowiedź jest przeciwieństwem odpowiedzi księgi Hioba, która wskazuje na pełnię mocy Stwórcy; moja wskazuje na Jego wyrzeczenie się własnej mocy. A jednak - osobliwe - obie są na Jego chlubę: albowiem Bóg zrezygnował ze swej mocy, abyśmy mogli istnieć. Jak sądzę, odpowiedzią dla Hioba jest również moja koncepcja: że cierpi w nim sam Bóg ${ }^{27}$.
\end{abstract}

Być może jednak powinny nam wystarczyć słowa samej księgi Hioba: „A skąd pochodzi mądrość / i gdzie jest siedziba wiedzy? (...) Bojaźń Boża - zaiste mądrością / roztropnością zaś - zła unikanie" (Hi 28, 20. 28).

${ }^{26}$ M. Fostowicz, Świat bez prawdy, Wrocław 2009, s. 117-118.

${ }^{27}$ H. Jonas, Idea Boga..., s. 4.6. 


\section{HANS JONAS AND ALAN WATTS: THEODICY AND THE SPECULATIVE MYTH}

\section{SUMMARY}

The article is a brief comparative work, whose subject are two different speculative myths. The first is the myth of English theologian Alan Watts; the second - the Jewish philosopher Hans Jonas. Both myths refer to the issues of theodicy. This article attempts to present the main thesis of both myths. Furthermore, it shows the specific role of a myth in the context of issues of theodicy.

KEYWORDS

Watts, Jonas, myth, theodicy, religion, speculation

BIBLIOGRAFIA

Fostowicz M., Boska analogia, Gdańsk 2008.

Fostowicz M., Swiat bez prawdy, Wrocław 2009.

Jonas H., Idea Boga po Auschwitz, tłum. G. Sowiński, Kraków 2003.

Leśmian B., W przeddzień swego zmartwychwstania, w: B. Leśmian, Łąka, Kraków 2009.

Marzęcki J., Artur Schopenhauer wobec filozofii Indii, Warszawa 1992.

Miłosz C., Ziemia Ulro, Kraków 1994.

Scherer B., Buddyzm, tłum. G. Kuśnierz, Kęty 2009.

Schopenhauer A., Świat jako wola i przedstawienie, tłum. J. Garewicz, Warszawa 1994.

Watts A., Beyond Theology: The Art of Godmanship, New York 1973. 